\title{
Scar endometriosis following hysterotomy: a case report
}

\author{
Sasikala $\mathbf{K}^{1}$, Nivedita Krishnamoorthy ${ }^{2}$, Shivaranjani $\mathrm{KS}^{3}$
}

Department of Obstetrics \& Gynecology, Sri Manakula Vinayagar Medical College and Hospital, Madagadipet, Puducherry, India

Received: 7 August 2014

Accepted: 19 August 2014

\section{*Correspondence:}

Dr. Nivedita Krishnamoorthy,

E-mail: niveog91@yahoo.com

(C) 2014 Sasikala K et al. This is an open-access article distributed under the terms of the Creative Commons Attribution Non-Commercial License, which permits unrestricted non-commercial use, distribution, and reproduction in any medium, provided the original work is properly cited.

\section{ABSTRACT}

Scar endometriosis is a rare entity mostly following obstetrical and gynecological surgeries and difficult to diagnose. It is often misdiagnosed as abscess, suture granuloma or lipoma. We report a case of scar endometriosis following hysterotomy - because of its rarity.

Keywords: Scar endometriosis, Suture granuloma, Hysterotomy

\section{INTRODUCTION}

Endometriosis is defined as the presence of proliferative endometrium outside the uterine cavity. Commonest site is the pelvis - Rokitansy first described it in $1860 .{ }^{1}$ Subcutaneous endometriosis of the abdominal wall generally develops at the site of previous abdominal surgery or pelvic procedures and the lesions are referred to as scar endometriosis. ${ }^{2-4}$ Incidence of scar endometriosis following hysterotomy is $1.08-2 \%$ whereas after caesarean section the incidence is $0.03-0.4 \%{ }^{2}$ Scar endometriosis is very difficult to diagnose, often confused with other surgical conditions and referred to general surgeons. The present study is a case of scar endometriosis following a hysterotomy.

\section{CASE REPORT}

A 24-year-old lady $\mathrm{P}_{3} \mathrm{~L}_{2}$ sterilized presented with painful nodular lesion on the abdominal scar, for the past 7 months associated with h/o dysmenorrhea and cyclical pain in the nodular lesion during her menstruation. Surgical history revealed hysterotomy done at 24 weeks along with sterilization 2 years back at a private hospital.

On abdominal examination- abdomen was soft, a well healed Supra pubic transverse scar with fixed, painful nodule- located on left lateral border of the scar, of size $3 \times 2 \mathrm{~cm}$ spherical in shape, firm in consistency and moderately pigmented. Per vaginum examination - uterus was anteverted, normal in size, mobile, fornixes free, and non-tender.

Her general and other systemic examination found to be normal. Routine investigations were within normal limits. Her transabdominal/transvaginal scan was found to be normal.

Provisional diagnosis was scar endometriosis or prolene granuloma and was posted for exploration of abdominal scar. Her intra operative findings revealed thickened subcutaneous tissue of $2 \times 2 \mathrm{~cm}$ of greyish color suspected to be an endometriotic deposit.

Lesion was excised sent for HPE. Postoperative period was eventful and patient improved symptomatically. HPE findings showed - fibro collagenous scar tissue with congested blood vessels adipocytes focal granulation tissue and hemorrhage.

The admixed foci show endometrial glands and scanty endometrial stroma. Few glands are surrounded by rim of endometrial stroma. Impression - Features suggestive of scar endometriosis. 


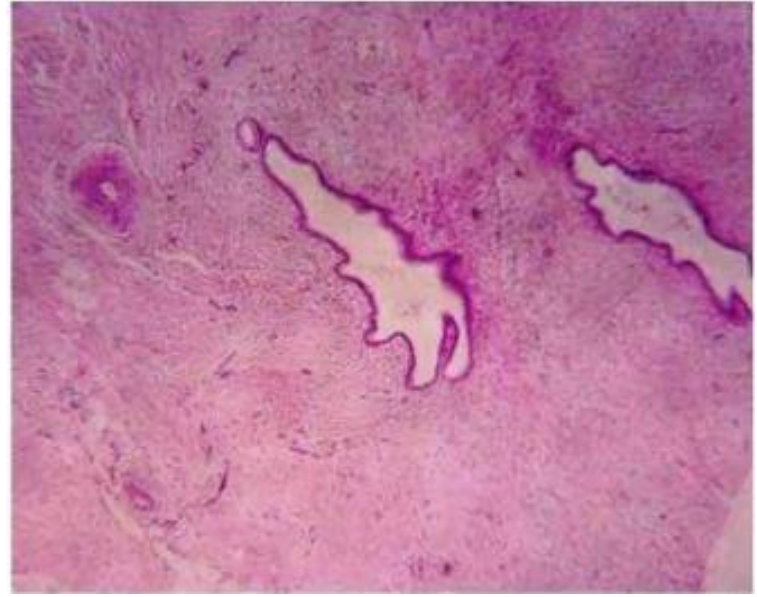

Figure 1: HPE findings showed - fibro collagenous scar tissue with congested blood vessels adipocytes focal granulation tissue and hemorrhage.

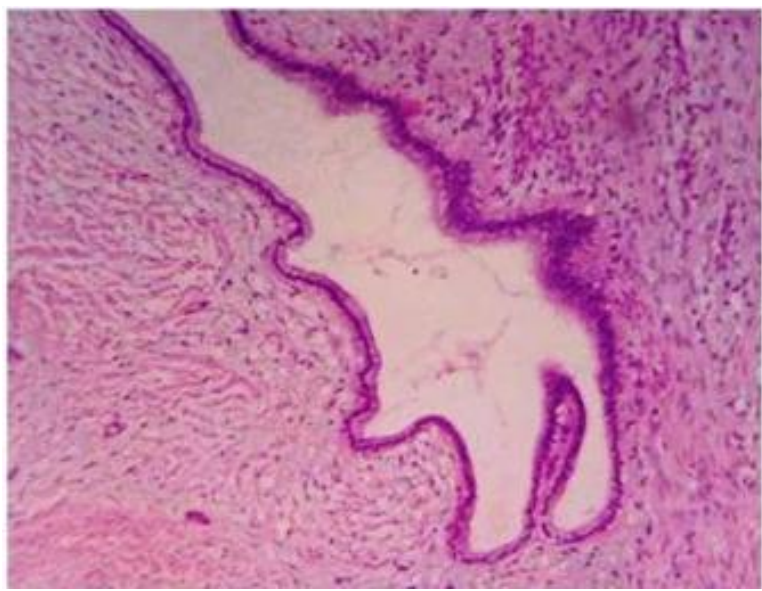

Figure 2: HPE findings showed - fibro collagenous scar tissue with congested blood vessels adipocytes focal granulation tissue and hemorrhage.

\section{DISCUSSION}

Scar endometriosis is a rare entity, which occurs following obstetrical, and gynecological surgeries. ${ }^{5}$ The incidence of scar endometriosis ranges from 0.03 $3.5 \%{ }^{1,6,7}$, Whereas the incidence following caesarean section was found to be $0.08 \% .^{8}$ Early hysterotomy (before 22 weeks of pregnancy) was found to be important risk factor for scar endometriosis. ${ }^{9}$ The incidence of scar endometriosis following hysterotomy is high because the early decidual cell have more pleuripotential capabilities. ${ }^{10}$ Elective caesarean section performed before the onset of labor doubles the risk of scar endometriosis. ${ }^{11}$ The condition is caused by direct inoculation of endometrial cells into abdominal fascia or subcutaneous tissue. ${ }^{12}$

Scar endometriosis can mimic conditions like stitch granuloma, inguinal hernia, lipoma, abscess, lymphoma etc. ${ }^{1}$ Scar endometriosis is a disease of reproductive age groups mostly seen in multipara. ${ }^{13}$ The clinical manifestation is usually a painful nodule of chronic cyclical nature related to menstrual period in the surgical scar area. This feature was typically seen in $66.7 \%$ of the patients in the retrospective study on scar endometriosis. $^{14}$

USG is most commonly used for diagnosis whereas MRI has a sensitivity of $90-92 \%$ and specificity of $91-98 \% .^{15}$ Histopathology is the gold standard for diagnosis which would show presence of endometrial glands, stroma and hemosiderin pigment. ${ }^{16}$ Wide local excision is the treatment of choice for scar endometriosis.

\section{CONCLUSION}

As it mimic varies conditions scar endometriosis should be kept in mind when dealing with a painful nodule on the scar in the reproductive age women.

Funding: No funding sources

Conflict of interest: None declared

Ethical approval: Not required

\section{REFERENCES}

1. Al-Jabri K. Endometriosis at caesarian section scar. Oman Med J. 2009;24:294-5.

2. Chatterjee SK. Scar endometriosis: a clinicopathologic study of 17 cases. Obstet Gynecol. 1980;56(1):81-4.

3. Firilas A, Soi A, Max M. Abdominal incision endometriomas. Am Surg. 1994;60:259-61.

4. Singh KK, Lessells AM, Adam DJ, Jordan C, Miles WF, Macintyre IM. Presentation of endometriosis to general surgeons: a 10-year experience. Br J Surg. 1995;82:1349-51.

5. Balleyguier C, Chapron C, Chopin N, Hélénon O, Menu Y. Abdominal wall and surgical scar endometriosis: results of magnetic resonance imaging. Gynecol Obstet Invest. 2003;55:220-4.

6. Esquivel-Estrada V, Briones-Garduño JC, Mondragón-Ballesteros R. Implante de endometriosis en cicatriz de operacióncesárea. Cirugía e Cirujanos. 2004;72(2):113-5.

7. Higginbottom J. Termination of pregnancy by abdominal hysterotomy. Lancet. 1973;1(7809):9378.

8. S. Minaglia, D. R. Mishell, C. A. Ballard. Incisional endometriomas after cesarean section: a case series. J Reprod Med Obstet Gynecol. 2007;52(7):630-4.

9. de Oliveira MA, de Leon AC, Freire EC, de Oliveira HC, Study SO. Risk factors for abdominal scar endometriosis after obstetric hysterotomies: a casecontrol study. Acta Obstet Gynecol Scand. 2007;86(1):73-80.

10. Sinha R, Kumar M, Matah M. Abdominal scar endometriosis after cesarean section: a rare entity. Australas Med J. 2011;4(1):60-2.

11. Wicherek L, Klimek M, Skret-Magierlo J, Czekierdowski A, Banas T, Popiela TJ, et al. The 
obstetrical history in patients with Pfannenstiel scar endometriomas: an analysis of 81 patients. Gynecol Obstet Invest. 2007;63(2):107-13.

12. Ridley JH, Edwards K. Experimental endometriosis in the human. Am J Obstet Gynecol 1958;76:783-9.

13. Rani PR, Soundararaghavan S, Rajaram P. Endometriosis in abdominal scars: review of 27 cases. Int J Gynecol Obstet. 1991;36(3):215-8.

14. Guilherme Karam Corrêa Leite, Luis Fernando Pina de Carvalho, Henri Korkes, Thiago Falbo Guazzelli, Grecy Kenj, Arildo de Toledo Viana. Scar endometrioma following obstetric surgical incisions: retrospective study on 33 cases and review of the literature. Sao Paulo Med J. 2009;127(5):270-7.

15. K. Kinkel, K. A. Frei, C. Balleyguier, C. Chapron. Diagnosis of endometriosis with imaging: a review. Eur Radiol. 2006;16(2):285-98.

16. C. P. Crum. The female genital tract. In: R. S. Cotran, V. Kumar, V. Collins, eds. Robbins Pathologic Basis of Disease. 6th ed. Philadelphia, Pa, USA: Saunders; 1999: 1035-1092.

DOI: $10.5455 / 2320-1770 . i j r \operatorname{cog} 20140977$

Cite this article as: Sasikala K, Krishnamoorthy N, Shivaranjani KS. Scar endometriosis following hysterotomy: a case report. Int J Reprod Contracept Obstet Gynecol 2014;3:854-6. 